\title{
The everlasting outmoded contraceptive method mix in Brazil and its legacy
}

\author{
Suzana Cavenaghi* \\ José Eustáquio Diniz Alves ${ }^{\star}$
}

Fertility transition occurred in a short period of time in Brazilian the absence of family planning programs, and most noticeable, in a context of illegality in the provision of means of fertility selfregulation. These events did not happen without consequences. Based in the literature and facts registered during that time, the paper first discusses how the resistance to the implementation of family planning programs from the 1960 s to the 1980 s have contributed to the unbalanced contraceptive method mix in the 1990's. Secondly, the paper will discuss problems around contraceptive data collection in the National Health Survey, and, performing an adjustment of the data, we analyze trends in the use of contraceptive methods from 1986 to 2013, showing that method mix continues to be very concentrated in the same two methods, an even more outdated scheme, with the daily pill exchanging first place with female sterilization. Finally, the paper discusses some fertility characteristics associated with the outdated contraceptive mix, still prevailing at the end of fertility transition, arguing that this could be avoided or minimized if policies and laws are based in reproductive rights of all people only.

Keywords: Contraception. Family planning. Brazil. Reproductive behavior.

\footnotetext{
*Independent researcher, Rio de Janeiro-RJ, Brazil (suzana_cavenaghi@uol.com.br; https://orcid.org/0000-0003-06273045).

${ }^{\star *}$ Independent researcher, Rio de Janeiro-RJ, Brazil (jed_alves@yahoo.com.br; https://orcid.org/0000-0001-6095-9668).
} 


\section{Introduction}

Exactly 20 years ago, analyzing contraception regimes, Potter (1999) discussed how the prevalence of specific contraceptive methods (method mix) was already outdated before the "advanced" technology existing at that time. Moreover, the author had argued that it would be very difficult to change the prevalence of specific contraceptive methods in the future, because a contraception regime "are subject to, and follows the logic of path dependence" (POTTER, 1999, p. 704). This is exemplified with the cases of Mexico and Brazil, where decisions and experiences from the past have determined current decisions, although the old logic or events are not currently pertinent. As discussed by Potter (1999), the outcomes in contraceptive use patterns might follow a diffusion process, but since changes are bound by the path dependency theory, this poses serious problems if the diffusion process has led to unsatisfactory outcomes, and therefore, changing these bad results, if at all possible, would take a long time.

Contraceptive method mix had shown that in the past the diffusion process of contraception, in the first decades of fertility transition in Brazil, was very unsatisfactory. Prevalence of modern contraception reached very high levels in the country by 1996 (76\% among married women), but women basically relied on two methods of contraception female sterilization and the pill, which together accounted for almost $80 \%$ of all methods. It is important to remember that female sterilization at that time was performed illegally in the public and private health sectors according to the prevailing laws (BERQUÓ; CAVENAGHI, 2003), and the pill was sold over the counter without prescription or follow up from physicians. Ten years later, in 2006, after the approval of the Family Planning Law (n. 9.263, 1996), some changes have occurred, with a significant decrease in female sterilization and small, but important, increases of the pill and two male methods - condom and male sterilization (PERPETUO; WONG, 2009). Although slowly, probably due to the path dependency theory, the new events and circumstances seemed to be changing, and contraceptive method mix looks as if it would start a less skewed route in the future, correcting some unwelcome previous results.

In spite of the importance of registering this transformation, since 2006, no other comparable data was collected in the country. Demographic and health surveys have not been carried out since then, and administrative records or other national surveys were not put in place. In 2013, for the first time, the Brazilian Institute of Geography and Statistics (IBGE) carried out a National Household Health Survey (PNS acronym in Portuguese). However, data on reproductive behavior was marginal in the survey, and the questions included on contraception did not follow international recommendations, thus not directly comparable to previous available data, ${ }^{1}$ generating doubts about the results with a probable

\footnotetext{
${ }_{1}^{1}$ Probably because of the unorthodox way of collecting information on contraception, the PNS 2013 data was seldom used right after data were made available. One of the few exceptions was the estimates for the World Contraceptive Use, 2017 〈https://www.un.org/en/development/desa/population/publications/dataset/contraception/wcu2017.asp〉.
} 
underestimation of female and male sterilization (LAGO, 2015). Another unexpected result was that the survey (IBGE, 2013) had indicated an overall decrease in the prevalence of contraception.

Conversely, recent estimates of mistimed and unwanted pregnancies from 2011/2012 (THEME-FILHA, 2016) indicated that unintended pregnancy continued to be very high, as it was in 2006 (BERQUO; LIMA, 2009). Hence, faced with a context of lack of suitable data, but knowing that fertility indicators show that universal access to reproductive health is not yet achieved, even so many years after the implementation of the Family Planning Law in Brazil, several questions arise: Is it possible to know whether Potter's assessment made 20 years ago, about the future of contraceptive method mix in the Brazilian case, prevailed or not? Why were family planning programs not successful in Brazil since the 1960s? Why did access to contraception follow such an unorthodox path? Has the Family Planning Law approved in 1996 guaranteed access to reproductive rights and the most suitable contraceptives to people looking for fertility regulation? What are couples, especially women, currently using to regulate fertility, which has been below replacement level since 2005 ?

With these questions in mind, this paper tries to shed some light in order to understand events that happened during fertility transition in Brazil, and how some biased practices of the past can be learned lessons, in the realm of reproductive rights and serve as guidance to achieve universal reproductive health and rights in the next decades. The general objective of this paper is to learn more about the contraceptive method mix in Brazil, understanding the choices left to couples in the realm of reproductive rights, and to discuss the unintended consequences of policies and actions on the current characteristics of contraception and fertility profiles.

The paper is organized as follows. First, based on past events and critical analysis available in the literature, it is argued that the resistance to the implementation of family planning programs from the sixties to the eighties has contributed to the unbalanced contraceptive method of the nineties. Secondly, a detailed comparison of the contraceptive data available from the DHS-like survey of 2006 (PNDS acronym in Portuguese) and the PNS survey is provided, proposing an adjustment of the data. Thirdly, a trend analysis of contraceptive prevalence in Brazil, by utilizing the adjusted 2013 estimates, is presented. The final section discusses how some adverse fertility profiles are associated with the contraceptive mix prevailing at the end of fertility transition.

\section{The historical resistance to family planning programs implementation}

By analyzing contraception regimes, Potter (1999) provided two excellent case studies, as recognized by Bongaarts and Johansson (2002). One of them, the case of Brazil, elucidated the processes that have led the country to a very restricted method mix in the 1990s. The author asserts that selecting new technologies is a complex process and recognizes that "history matters, sometimes more than underlying preferences, endowments, and 
opportunity sets" (POTTER, 1999, p. 714). The author lays out accurately how the pill and female sterilization became highly used at that time, and draws attention to the adverse effects. For example, since female sterilization was illegal, some of the widespread solutions found by women seeking fertility regulation was getting the surgery during a delivery by c-section (POTTER, 1999) increasing beyond reason births by c-section, or exchanging surgery for votes (CAETANO; POTTER, 2004) in an unfortunate quid pro quo practice.

This crucial analysis provided by Potter (1999), using two different settings (Mexico and Brazil), shows how understanding the outcomes of method mix is complex. Although the author recognized the damaging consequences of improper family planning provision, he did not discuss why public and private family planning (FP) programs were not successfully implemented in Brazil, given all the international pressure to decrease population growth in the 1960's. Indeed, family planning programs were, and still are in some settings, linked to the idea of coercive population control; nonetheless, family planning is primarily a right. As contended by Bongaarts and colleagues (2012, p. v), "[family planning programs] help women achieve their Human Rights to health, autonomy, and personal decision making about family size".

However, voluntary family planning programs are essential for achieving universal access to contraception and avoiding unintended pregnancies, it is highly acknowledged that the Brazilian Government did not put in place policies to provide public FP programs in Brazil (CANESQUI,1985) in the 1960's and 1970's. Certainly not one single motive can be put forward to explain why FP programs were unsuccessful in Brazil. Not ignoring all the complexities around the topic, the argument here is that this was possible because there was great resistance, due to different ideological positions, and coming from many different actors and in different forms, regarding the provision of modern contraception. And, exactly because this resistance came from different sectors operating at once, it was probably the most effective in preventing the implementation of FP programs, in the public and also in the private sectors. The result, probably not intended, was that access to reproductive health services to all population segments was denied to women, but harming mostly the poorest, who had more difficulties finding ways around realizing a desire.

Indeed, not only in Brazil, but in several Latin American countries, before fertility transition started at the national level, during the 1960s, governments, the Catholic Church, as well as politicians from the left wing, for different reasons, have opposed the adoption of FP programs, as well documented by Taucher (1979). Correa and Alves (2003) go further and assert that these "alliances" in some countries, as was the case in Brazil, seemed even most improbable, because they put the military, the Catholic Church and most feminists groups on the same side: against the implementation of FP programs at public or private spheres, not in name of rights to a public policy, but for specific reasons, all of them with ideological biases.

Regarding the military position on family planning, in Brazil it is well documented that the government adopted a laissez-faire policy towards FP programs (MARTINE; FARIA, 1986). The military government had to deal with a contradiction between the national policies, which can be summarized as "bringing landless men to a man-less land" (ALVES; MARTINE, 
2017, p. 45), and the international pressure to control population growth. The authors, based on an analysis by Canesqui (1985), emphasized:

[...] Despite the precarious living conditions of the majority and the lack of investment in the welfare of the population, the first military governments supported a pro-natalist policy. Several documents, including the National Security Policy (1964-1970), the Strategic Development Program (1968-70) as well as the government's official reaction to the conservative Humanae Vitae encyclical (1968) reaffirmed the government's pronatalist ideology as well as its concern with the occupation of remaining open spaces. (ALVES; MARTINE, 2017, p.42)

The government's position on population dynamic would undergo modifications during the 1970s, and the pro-natalist view shifted to a discourse of rights to information and access to family planning (MARTINE; FARIA, 1986). However, as the authors affirm, this official position, presented in the 1974 International Population Conference, did not change government actions allowing for the provision of family planning, though it might have facilitated the action of some nongovernmental organizations and private organizations in some parts of the country. The laissez-faire policy on public family planning provision would continue for the next decade in Brazil, with a modest action with the Maternal and Child Health Program in 1977, which did not have a significant impact (ALVES; CORREA, 2003).

In relation to the clergy and the Catholic hierarchy, they did not only oppose FP programs, but also the use of all forms of contraception, mainly the modern methods. The Humanae Vitae encyclical (1968) states that marriage is an indissoluble sacrament performed for a generative purpose and avoiding children would be a serious sin. In this regard, in the 1960s, the Catholic Church reaffirmed its opposition to the use of contraception, mainly artificial methods, and used all its influence in every possible forum, to hinder the implementation of FP programs as governmental policies, and in private spheres. Notwithstanding, it is important to note that a number of Catholics were certainly practicing contraception and/or induced abortion, since $99 \%$ of the population were Catholics, according to the 1960 Demographic Census, and the total fertility rate at State level was already around 4.5 children per women in Rio de Janeiro and São Paulo and about 9.1 in the Amazon, according to 1960 Census estimates (IBGE, 1985).

With regard to the majority of feminist groups immersed in women's liberation movements at that time, although in favor of fertility auto-regulation and fighting for women's rights, they had grounds to think that FP programs, mostly dependent on international aid, would be a way to control women's body. This made the movement strongly oppose the provision of modern contraceptives in programs with international assistance, and had strong activism against the implementation of FP programs at all levels. Thus, although feminist groups were in favor of women's choice regarding the freedom to choose the number of children and of all women's rights regarding reproductive health, this opposition worked in favor of those hindering, or not facilitating, the provision of modern contraceptive methods by legal or public channels. 
The consequence of this resistance was that only in 1996, when fertility rate was already below 2.5 children per women (Projeto IBGE/UNFPA), was a Family Planning Law passed in the country, although since the 1988 Federal Constitution, reproductive rights were recognized in Brazil. Still, the law was passed with a complete veto to the female sterilization article, which was overturned only a year and a half later. In fact, this unfortunate event postponed until 1999 the legal provision of female sterilization in the public health system (BERQUÓ; CAVENAGHI, 2003).

However, after a large decline in infant mortality rates since the 1940 s and 50 s, were women and couples really capable of exercising their preferences on family size? Were there no evidences of women's desire for fertility control at that time? As Carvalho and Brito (2013) asserted, the results of the 1970 Demographic Census and the 1972 and 1976 PNAD, would come with an enormous surprise because all demographers, Brazilian and even some Latin Americans, could not believe that fertility was declining because of a commonly believed truth: "there was no widespread demand in the country for the reduction in the number of children and, consequently, for contraception" (CARVALHO; BRITO, 2013, p. 359). Although fertility was declining, some theories were put forward to explain why large families made sense in the political, cultural and economical context (PAIVA, 1987). Also, some thesis defended that a large number of children made sense as families' survival strategies, transposing to urban settings the experiences and conditions of rural locations (PATARRA; OLIVEIRA, 1988).

Looking at material published at that time, it seems clear that in several Latin American Countries there already was plenty of evidence of voluntary fertility regulation during the 1960s, when total fertility rate (TFR) was high around 6, in both rural (SIMMONS et al., 1979) and urban settings (CELADE; CFSC, 1972). For instance, the results of the World Fertility Survey (WFS), carried out in 13 countriesin the 1970s, found that the number of wanted children was smaller than the observed (UNITED NATIONS, 1987). Furthermore, those surveys pointed to large proportions of women who wanted to stop having children when reaching the second or third child. Moreover, there was evidence of a large number of women voluntarily interrupting pregnancies, even under illegality, and registering high maternal mortality rates due to unsafe abortions (CEPAL, 1992) in the region. Was then Brazil an exception?

Although Brazil never participated in the WFS, ${ }^{2}$ maybe one of the best signs of the resistance to learn about women's intentions, in the country there was already enough evidence of women were controlling their fertility in the 1960 s, or even before, in some

\footnotetext{
2 Brazil declined to participate in the World Fertility Survey in the 1970s, and also in the early 1980 s, carried out in 66 countries with comparable methodology, to collect demographic data about human reproduction, since apparently the main objective of that survey was evaluating the effectiveness of family planning programs. As Carvalho and Brito (2013) affirmed, demographers, in an assembly of the association, voted against the participation of the Brazilian Institute of Geography and Statistics (IBGE) in the WFS in the beginning of the 1980s. It is interesting to note that the ballot result had many abstentions (18), where 14 voted in favor of the realization of the survey, and 28 against. The consequences of this act, of a small but influential group, continued for decades, and the Institution never undertook the responsibility of collecting regular data on family planning and reproductive health as part of its agenda.
} 
areas and for some population segments in the country. For instance, not only the most privileged wanted to regulate their fertility in the 1960s, but also the poor, at least in urban areas. Martine (1975) recounted the particular tragedies of women who could not regulate their fertility, in a qualitative masterfully executed survey, carried out among lower class population in Rio de Janeiro. The author showed there was ample evidence that induced abortion was highly used, and that contraception was an almost widespread desire among poor sectors of the population, living in urban areas of the city.

Notwithstanding these evidences of preference for smaller families, the "tacit alliance" against the implementation of FP programs (CAVENAGHI; ALVES, 2019) has helped to make it difficult for most couples to access modern contraception. Even if unintentionally, all sides denied rights to the population, as stated by Carvalho and Brito (2013) regarding the position of some demographers on this issue, and this position affected the population most in need of adequate access. In the words of the authors: "The result was an unforeseen complicity, with a perverse effect on the poorest population, translated into a deep silence about their right to regulate fertility" (CARVALHO; BRITO, 2013, p. 362).

If the silence about rights prevailed, the manifestations against family planning were not silent. The resistance and criticism to "family planning programs" have made the words "family planning" almost unpronounceable in several areas, including academia, for decades in Brazil. It has almost become a synonym of "population control" worldwide. However, maybe the biggest problem with the term is that it could drive young people away or those who are trying to exercise the right of not starting a family (CAVENAGHI, 2009). As Carvalho and Brito (2013) recognized, the attitudes and positions of population scientists in denying the occurrence of fertility transition before the 1980s in Brazil, even assuming positions that would work against Human Rights, especially women's rights, should serve as an example today. As the authors stated, "May this critical assessment of our mistakes and silences in the past helps us not to reproduce them in the present and in the future" (CARVALHO; BRITO, 2013, p. 366).

With this context in mind, the next sections of this article seek to show how past attitudes, that failed to put the reproductive rights of individuals at the core, have been and continue to be detrimental to the population, as discussed along the text. First, a reflection on the inadequate data for a complete analysis, followed by the almost incomprehensible trends in contraceptive method mix, and finally, drawing attention to the adverse legacy for women's reproductive health and lives and several constraints in the exercise of fertility preferences.

\section{Data to analyze the trends in the prevalence of contraceptive use}

An analysis of the tendencies of contraceptive prevalence in Brazil is a difficult task, since the country is not a good model of collecting data on contraceptive use timely and accurately. Data were not collected at the beginning of the fertility transition period, or recently. The first national data on contraceptive prevalence at national level are available 
only for 1986, from two different surveys: the 1986 Demographic Health Survey (DHS) carried out by a Non-Governmental Organization (NGO), Bemfam, with international aid, applied to women 15-49 years old, and the 1986 Pesquisa Nacional por Amostra de Domicílios (PNAD) carried out by IBGE, applied to a subsample of women aged 15 and over (CAVENAGHI, 2006).

By 1986 , fertility had already fallen to about 3.4 children per woman, according to the 1986 DHS, well on the way to fertility transition. Five years later, in 1991, the DHS was carried out only in the Northeast region, where fertility was estimated at around 3.5 children per woman in the region. The next survey informing about contraceptive practices at national level was carried out only ten years later, in 1996, again, with international aid and run by the same NGO, when fertility was around 2.5 children in Brazil. Although there was an international recommendation to collect demographic and health surveys every five years, with the end of international aid, only in 2006 was the Brazilian Ministry of Health able to conduct a national survey (Pesquisa Nacional de Demografia e Saúde - PNDS), which followed the format of the DHS program fifth wave, but was an independent survey.

It is worth noting that information on female and male sterilization is available in the administrative records of the public health system, since they are surgeries. However, they do not provide prevalence data, only incidence. Most importantly, the administrative records have incomplete coverage, since they only consider the public sector, which covers about $70 \%$ of medical services. Moreover, data quality is different over the years and the territory, and female sterilization was registered under different medical procedure codes when it was illegal or performed during c-sections (BERQUO; CAVENAGHI, 2003).

It is important to mention that the national official statistical institution (IBGE) did not collect any information about contraception after the supplement of the 1986 PNAD, except more recently in the first National Health Survey (PNS - Pesquisa Nacional de Saúde) in 2013, which included questions of contraceptive use. ${ }^{3}$ However, this information presented several problems besides not being directly comparable to the previous existing data as previously mentioned.

In this context, to analyze tendencies in contraceptive method mix, all three DHS like surveys, 1986, 1996 and 2006, are used here. Additionally, not accurate but still useful, the PNS 2013 data are used as the more recent data. The surveys are made more comparable, when possible, and a simple adjustment is proposed for the prevalence of use, which is underestimated in the survey, and redistributed among some contraceptive methods.

\footnotetext{
${ }^{3}$ IBGE had planned to carry out a PNDS survey in collaboration with the Ministry of Health and jointly with the new wave of the 2018 PNS; however, the plan did not follow through, and even the PNS was postponed to 2019. Currently, with the urgency of the Demographic Census, a planning to have a PNDS carried out by IBGE seems very unlike for 2020. Exactly the same questions, without the needed corrections, on contraception included in the PNS 2013 are considered in the 2019 PNS. Most unfortunately, although the intentionality of birth is included in the 2019 questionnaire, if it was planned, or the result of a mistake, is being asked only to menand not to women in the survey, according to the questionnaire in the field.
} 


\section{PNS and PNDS contraceptive data: trying to make them more comparable}

The PNS is the first nationwide household survey exclusively devoted to collecting health information, and was planned for more than 10 years between the Ministry of Health and IBGE. Previously, some selected health issues were part of specific modules or supplements of the annual PNAD. In 2013, the Health National Survey (PNS) became part of IBGE's Integrated System of Household Survey (SIPD in Portuguese), and one year later, IBGE had started a new design for the annual household surveys (Continuous PNAD). Regarding reproductive health, PNS collected information on preventive exams, reproductive history, and family planning (IBGE, no date).

The approach to select the target population at PNS implies two differences in data collection with respect to the PNDS design. The first difference is the age range: PNDS includes women aged 15-49 and PNS women aged 18 and over. Although it would be very important to learn about the behavior of contraceptive use among teenagers, in this paper, for comparison purposes, contraceptive prevalence is analyzed only for women aged 18-49 years old. The second difference is the selection of the respondent within the household. In the PNDS, all women of reproductive age within the household are eligible, and in the PNS, only one of them, among the aged 18 and over, is randomly selected to answer the questionnaire. Although a post-selection of one woman per household could have been done, in order to make the surveys more comparable, since this would reduce the sample size of PNDS, and also due to the fact that the analysis would be done only for married women or in union, the selection of one respondent at PNDS was not done here.

With regard to family planning and contraceptive use, the questions in the PNS begin with sexual activity in the last 12 months (R.31), and only women with sexual activity (and at risk of becoming pregnant) responded if they were currently using any method to prevent pregnancy. However, the universe of women, considered at the PNDS, can be recovered from the questionnaire filters at PNS. Hence, the total number of women of reproductive age in the PNS included those who were not sexually active, those who were pregnant and not sexually active, women who were hysterectomized (question R.10) or amenorrheic (question R.26) ${ }^{4}$ (IBGE, 2013), following the PNDS approach.

Current use of contraception is not defined in the PNS 2013, and it is up to the respondent to define what is meant by current. However, since the question comes after one on sexual activity in the last 12 months, it can be inferred that the period of reference is in the respondents' mind, even if there was not a method consistently used in the previous 12 months. In the PNDS, current use is considered to be the last month. This incompatibility between surveys cannot be overcome and the differences cannot be dimensioned, because it would need a specific pre-survey test. It is assumed, though, that the high prevalence

\footnotetext{
${ }^{4}$ A failed assumption in the PNS 2013 questionnaire design is that hysterectomized or amenorrheic women do not have sexual activity. That is, sexual activity in the PNS is underestimated.
} 
of modern methods and the multiple answers for different contraceptives would minimize possible differences.

Another problem in the approach to collect contraception data in the PNS refers to a probable prevalence undercount, because PNS 2013 did not include probing questions about knowledge of contraceptives types. It is well established in the literature that not having probing questions on different types of method can lead to an underestimation of contraceptive prevalence (UNITED NATIONS, 2018). However, since a large list of contraceptives was mentioned with a yes/no answer for each method, and allowing for multiple responses, the undercount due to the lack of probing questions would not be significant, if the list is complete. Nonetheless, two other problems in the questionnaire design, regarding the list of contraceptives, could have compromissed - not only the overall percentage of users -, but also the type of methods declared by women.

Firstly, the list of contraceptives is not presented in order from the most effective to the least effective method, as recommend and used in the PNDS-DHS. Secondly, and most critical, female and male sterilization are not presented in the list. In the questionnaire design, these two methods were not considered contraceptive methods, but instead were included as reasons for not using any method to avoid pregnancy. Since the question is designed to have a spontaneous response, getting the right information will depend on the interviewers and the training they received. With that in mind, it is expected that by design male and female sterilization will be undercounted in the PNS, and an adjustment to these data is proposed and described in the next subsection.

The indicators selected to analyze trends in contraceptive prevalence and method mix in Brazil were those recommended for international comparison. The target population used includes married or in-union women, regardless of their pregnancy status and presence of menstrual period. Although it would have been more accurate to use only women at risk of pregnancy, due to different definitions in each survey, the international recommended approach was applied in the analysis. The method-specific prevalence was then used to analyze method-mix.

The distribution of women by contraceptive use was, in turn, estimated by combining the questions on motives for not using and the list of contraceptives, and by ordering the answers from the most effective to the least effective method. The order assumed to select the method used for each woman was: vasectomy, tubal ligation, IUD, implants (Norplant), injectables, pill, emergency contraception (morning-after pill), diaphragm, male condom, female condom, table, and creams. To complete the universe of sexually active women, those who did not respond that they used any of the above methods were classified as sexually active and not using contraceptive method. This distribution, estimated at the individual level, will probably underestimate contraceptive prevalence, so an adjustment was performed at the aggregate level. 


\section{Adjusting the aggregate prevalence of contraceptive use in the PNS}

In the methodological report (IBGE, no data), there is no plausible explanation for not considering tubal ligation and vasectomy as contraceptive methods. A consultation with the survey manager at IBGE reported that the decision was made by the technicians from the Ministry of Health who designed the questionnaire. This question format, apart from not considering the comparison with internationally tested models for the collection of information on contraception, does not take into account that in Brazil, sterilization, mainly female, is used in large scale as a contraceptive method. In fact, among the available methods, although it is non-reversible, sterilization has the lowest failure rate. At any rate, this can also be a sign of how, after so many years, some health professionals still consider what is a contraceptive method or not, and which perhaps should not be available to the population as such.

As expected, the observed distribution of contraceptives on in 2013, using the previous definition, indicates a sound decrease in the prevalence of male and female sterilization, which was not compatible with the number of surgeries performed annually in the public sector, available in the administrative records "Authorization for Hospitalization" (AIH). This result confirmed previous assumptions about the possible undercount due to the questionnaire design.

Most important, considering all women aged 18-49 in both surveys, the results would also indicate that contraceptive prevalence would have decreased from 2006 to 2013, which also seemed very improbable in the context of continuous decreasing of total fertility rates in the period, which in 2015 was around 1.8 children per woman. Hence, to adjust contraceptive prevalence rates for the country and for each specific population segments, it was assumed that the percentage of women not using contraceptive methods in 2013 was at least the same level it had been in 2006 (last PNDS), considering the same target population in both, all married or in-union women aged 18-49. For instance, in 2006, this percentage was $19.0 \%$ for the country and the same value was set for 2013 , at the aggregate level. For each population segment, the same procedure was applied, since the prevalence of not using contraception is differential by women's characteristics.

The undercount for 2013 was estimated at $8.3 \%$ for the country (i.e., 19.0\%-27.3\%), which was redistributed in relation to the most probable undercounted methods in the questionnaire design, female and male sterilization, as discussed previously. For other segments, this estimation of contraceptive prevalence varied from zero to $20 \%$. The highest undercounts were found among women at the end of reproductive ages, with low schooling, living in the North Region, and with higher parities. On the other end, the lowest undercounts appeared among women aged 18-24 and with zero children, indeed with zero undercounts, which is the same value for not using contraception in the PNDS. The variables considered were place of residence, region, race/color, education, female labor force participation, age, and number of children ever born. 


\section{Contraceptive trends}

\section{Prevalence of contraception}

Brazil, as well as several other Latin American countries, presents very high contraceptive prevalence rates. Indeed, they are too high when compared to developed countries and confronted with the levels of reported mistimed and unintended pregnancies. One of the reasons is that for comparative purposes, contraceptive prevalence rates (CPR) are not calculated for all the population at risk, but only for married and in union women. In Brazil, sexual activity is frequent among single women, and the first use of contraception, usually happens only after the first pregnancy. Another possible reason, a very high CPR and high unintended births, might be associated to contraceptive failure, largely beyond the expected failure rates for each method, most of times due to misuse or discontinuation of the methods, but mainly because of the poor quality of family planning care which persists in the country (THEME-FILHA, 2016).

Graph 1 presents the percentage of married or in union women who were using modern and traditional contraceptive methods since 1986. The first four bars present the original data and the last two bars the adjusted value for 2013, and also considering only women aged 18-49 for 2006 PNDS. As observed, along these years, the increase of contraceptive prevalence is very significant, as well as the increase of modern contraception. The percentage of using any contraceptive method among married and in-union women increased from $66.2 \%$ in 1986 to $76.7 \%$ in 1996 , reaching $80.6 \%$ in 2006 , while traditional methods decrease to less than $3 \%$. The original data for the 2013 PNS survey, as mentioned before, show a significant increase in the percentage of women not using any type of method (from the previous $19 \%$ to $27.3 \%$ ). It is interesting to note that mostly modern contraception presented a decrease according to the 2013 original data, thus indicating an undercount.

GRAPH 1

Contraceptive prevalence rates among married or in-union women by different data sources Brazil - 1986-2013

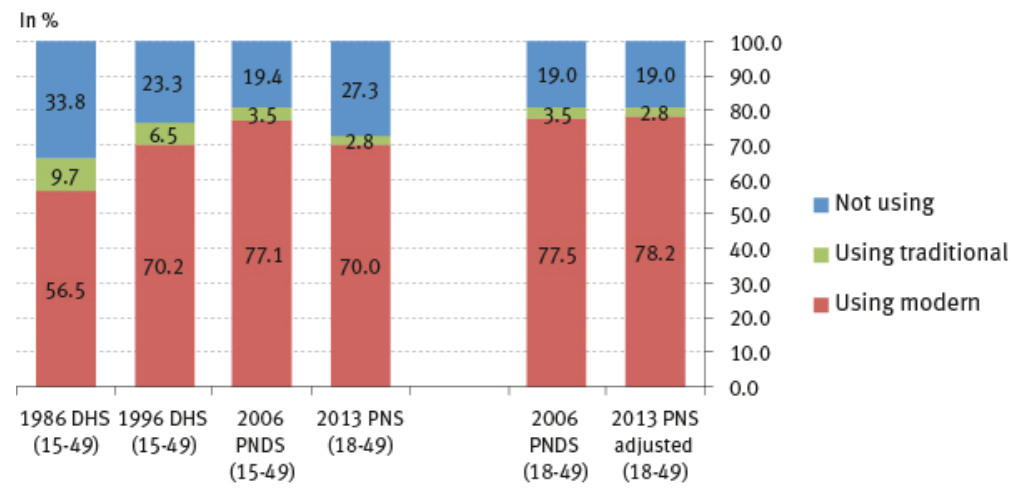

Source: ICF (2012) for 1986 and 1996 data, PNDS microdata for 2006 data; IBGE, Pesquisa Nacional de Saúde, 2013. 
The last bar inGraph1showsthe adjusted estimate for the CPR in 2013, by relatively redistributing the difference of non-users to male and female sterilization in 2013, as described previously (setting the not using at 19\% in 2013). The adjusted estimate shows that $78.2 \%$ of married or in-union women aged 18-49 in Brazil in 2013 were using a modern contraceptive method to prevent pregnancy. This represents a small increase from the previous estimate of modern CPR, $77.5 \%$ in 2006 . Regarding traditional methods (not adjusted), there was a decrease from $3.5 \%$ to $2.8 \%$ of married or in-union women relying on those methods, following the declining tendency since 1986. This increase of modern contraception and decrease of traditional methods follows the global trend (UNITED NATIONS, 2015), and thus seems more reliable than the original collected data.

\section{Prevalence of contraception by methods}

It is important to mention that contraceptive method mix varies enormously across time and space, and there is probably no single distribution of methods that can be pointed out as indicating that reproductive health rights are fully achieved (UNFPA, 2016), but at least these events are highly related (BIDDLECOM; KANTOROVA, 2013, UNITED NATIONS, 2015). On the other hand, if a very narrow list of methods accounts for most use (ROSS; KEESBURY; HARDEEB, 2015), and more importantly, if some of the best recognized contraceptive methods are not among the most used, it can be argued that family planning services are defective, or that there are strong social, cultural or economical barriers to contraceptive access (POTTER, 1999). These background hypotheses are used here to assess if women and couples have universal access to reproductive rights.

Although the types of contraceptive methods present in the method-mix varies widely across the world, relying mostly on two methods is a worldwide trend (UNITED NATIONS, 2015), and Brazil followed this rule in the 1990's as well as in the present. One enormous difference, though, is that whereas the use of IUD, both hormonal and non-hormonal, has increased almost everywhere in the world, and is among the most used, in Brazil, figures for IUD prevalence were negligible throughout fertility transition up to the most recent date, and practically do not appear in the bars of Graph2, which presents CPR by methods for different years.

Another different trend observed in Graph 2, compared to world patterns, is related to other hormonal methods. While some countries move towards injections (UNITED NATIONS, 2015), which are considered a long acting reversible method, in Brazil, the daily pill was one of the methods most used in the past and has gained even more prominence, reaching $30.8 \%$ among married or in-union women aged $18-49$ in 2013 . It indicates that a very large proportion of women probably continue obtaining their contraceptive method over the counter, without prescription, and many without medical follow-up. What is not yet reflected in the 2013 data is the emergency contraception, known as "the next day 
pill”, also based on high doses of hormone, and frequently sold in drugstores, mostly for younger women (OLSEN et al., 2018).

The other most prevalent method in Brazil, female sterilization, increased enormously until 1996, reaching 40.1\% among married and in-union women aged 15-49, which implies it was selected by $52.3 \%$ among the contraceptive users of that group. In the period following the approval and implementation of the Family Planning Law (1996), when female sterilization could be legally provided, its prevalence had decreased to $29.1 \%$, according to a 2006 survey. This decrease continued in the next period, for women aged $18-49$, from $29.8 \%$ in 2006 , to $26.1 \%$ in 2013.

GRAPH 2

Contraceptive prevalence rates of specific methods among married or in-union women by different data sources Brazil - 1986-2013

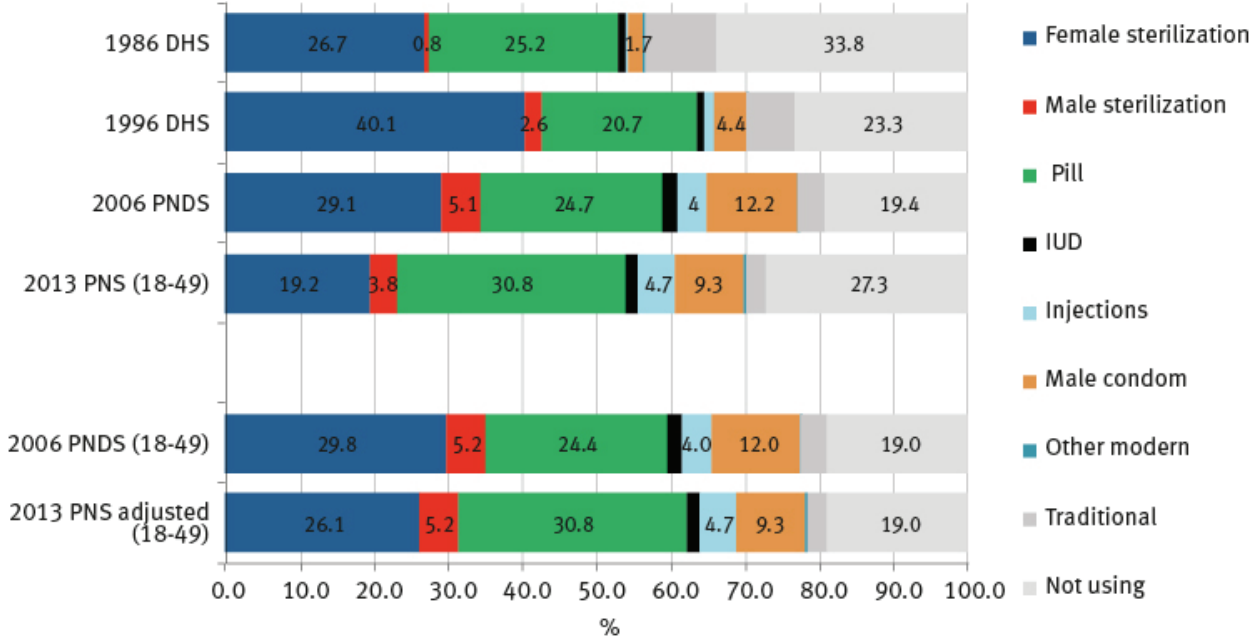

Source: ICF (2012) for 1986 and 1996; PNDS microdata for 2006; IBGE, Pesquisa Nacional de Saúde microdata for 2013.

A small part of this change in female sterilization can be attributed to a modest increase in male sterilization; from $2.6 \%$ in 1996 to $5.1 \%$ in 2006 , as declared by women aged 15-49. Hence, the implementation of the legislation has probably increased access to this contraceptive for men, but not necessarily for women. The next period though, male sterilization prevalence seemed to have stalled, staying at 5.2\% in 2013. Male participation in contraception also increased with the use of male condom, ${ }^{5}$ from $4.4 \%$ to $12.2 \%$ from 1996 to 2006 . However, since this increase was mostly among the young, it is more likely to indicate a result of the HIV campaigns of that period rather than changes in family planning itself (BERQUO; CAVENAGHI, 2005). This can be confirmed by the decrease of condom use in 2013, as shown in Graph 2 (last two bars).

\footnotetext{
${ }^{5}$ It must be pointed out that the male condom can be underestimated and is only defined as the main method if no other more efficient method was reported by the woman.
} 
These reversed trends between female sterilization and the pill deserve much attention. It is contended that the legislation on family planning in Brazil was not approved only to assure rights long denied to the Brazilians. The law was designed with the intention of changing contraceptive mix, since it was seen by policymakers and some groups as wrong outcomes, which resulted from the restrictions imposed to the population who wanted to regulate their fertility. That is, as Potter (1999, p. 730-731) has asserted, the Brazilian FP legislation's "specific goals were to reduce the number of sterilizations that are undertaken prematurely, to increase the use of methods other than the pill and sterilization, and to reduce the number of cesarean section deliveries".

The 2006 data indicate that the goal of policymakers was going in the expected direction, since, after the legislation had been implemented, female sterilization was decreasing, other methods were slowly being introduced (male sterilization and injections) and male participation in contraceptive use was increasing. Nonetheless, the lack of long acting reversible contraception (LARC), such as the IUD and implants, was showing that the entire bulk of contraception was still not accessible. Already available in most countries at that time, the IUD is more effective than the daily hormonal pills for preventing unwanted pregnancies (PEIPERT et al., 2011; TRUSSELL, 2011).

As Potter (1999) asserted, history had shown that not making contraceptive access universal to all the population had created deviations with an outmoded contraception regime in 1999, with high prevalence of one permanent method and a low prevalence of long acting reversible contraceptive methods. The 2013 data confirmed that something is still making access to the entire bulk of contraception in Brazil, difficult and that it seems to be moving in an even more outmoded direction. Male sterilization did not takeoff yet, other effective LARC are still missing, and although female sterilization has decreased, the daily pill took its place. Hence, 20 years after its implementation, family planning legislation did not help improve contraceptive method mix in the country, and may have contributed to making it worse in some situations, such as by making it harder for individuals who have achieved fertility preferences and are not willing to run the risk of an unwanted pregnancy to get sterilization.

\section{Method mix across different population segments}

A selection of contraceptive a couple/person will depend, primarily, on personal characteristics related to life course, such as age and number of children. In this sense, looking at CPR for specific methods within population groups can give a better picture of outcomes that might not occur by chance. Graphs 3 and 4 present CPR by methods for some geographical, socioeconomic and demographic variables, respectively for Brazil in 2006 and 2013, for married or in-union women aged 18-49. For almost all population segments, the rule of two methods accounting for most of the prevalence seems to be the norm in both periods, and those methods are female sterilization and the pill, exchanging places if women are in the beginning, middle or end or their reproductive life or have few or a few more children. 
The trends in the period must be analyzed with care, because of the adjustments performed in the 2013 data, but as for the national figures, in all population subgroups, it can be observed an increase in the prevalence of the pill from 2006 to 2013 and a decrease in female sterilization. That is, the data indicate that the changes in contraceptive prevalence occurred for all population segments, with an important increase of pill and an almost complete absence of IUD and implants for all groups. Regarding sterilization, it is worth noting that the most educated were using male sterilization in a significant proportion in 2006, but in 2013, the general trend seems to be decreasing for female sterilization.

Women living in rural areas, less developed regions, with 0-8 years of schooling, who responded black or brown as skin color, aged 35 or over, and with two or more children, were using female sterilization more than the pill in 2006 to avoid pregnancy. The trends in the period did not cause a reversal between the two most prevalent methods for these groups, as the tendency observed at national level. That is, even in 2013 , female sterilization continues to be the most prevalent method among these groups.

Moreover, female sterilization was more frequent than the pill among women living in urban areas and the Southeast region, indigenous and who responded yellow for skin color, and those who participated in the labor market. In 2013, these population segments presented a reversal, and the pill became more prevalent than female sterilization. That is, the trend observed at national level was induced by these groups, but also, corroborated by the increase in other groups that were already using the pill more since 2006: white women; living in the South region; with 9 or more years of schooling; 0-1 children ever born; aged 18-34.

It is important to mention that life course seems to respond as expected among the selection of these two methods. Female sterilization is the most used method among women 35 years and above and who have had two or more children. As discussed before, the early fertility schedule in Brazil can explain this outcome, since after reaching the desired number of children, using a method with a low risk of failure makes more sense than to be subject to an unintended birth or to a pregnancy interruption. What can be questioned, though, is the lack of other LARC or even the low prevalence of male sterilization. 
GRAPH 3

Contraceptive prevalence rates of specific methods among married or in-union women aged 18-49 by selected socioeconomic and demographic groups Brazil - 2006

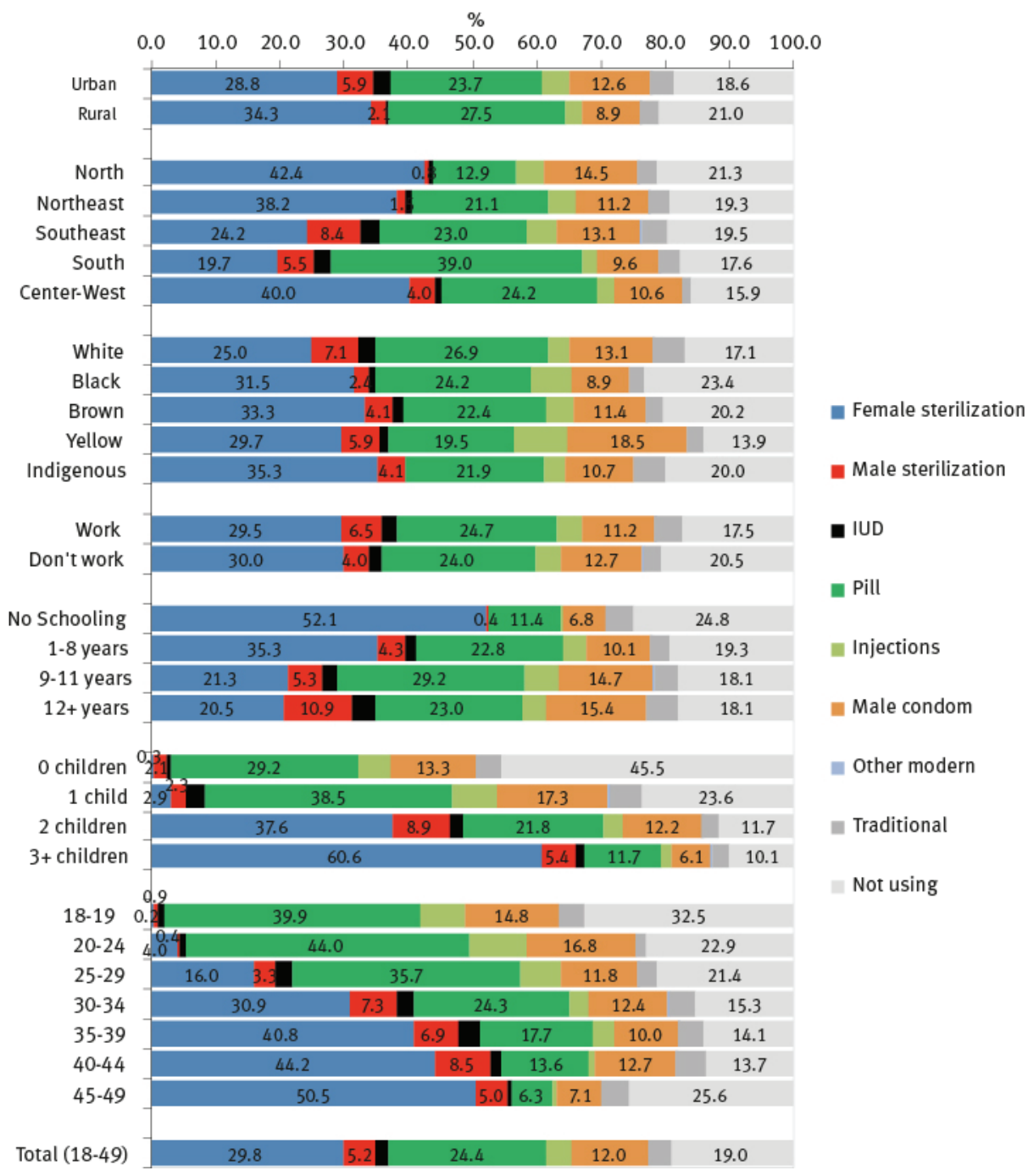

Source: Brazil, Pesquisa Nacional de Demografia e Saúde, microdata, 2006. 
GRAPH 4

Contraceptive prevalence rates (1) of specific methods among married or in-union women aged 18-49 by selected socioeconomic and demographic groups

Brazil - 2013

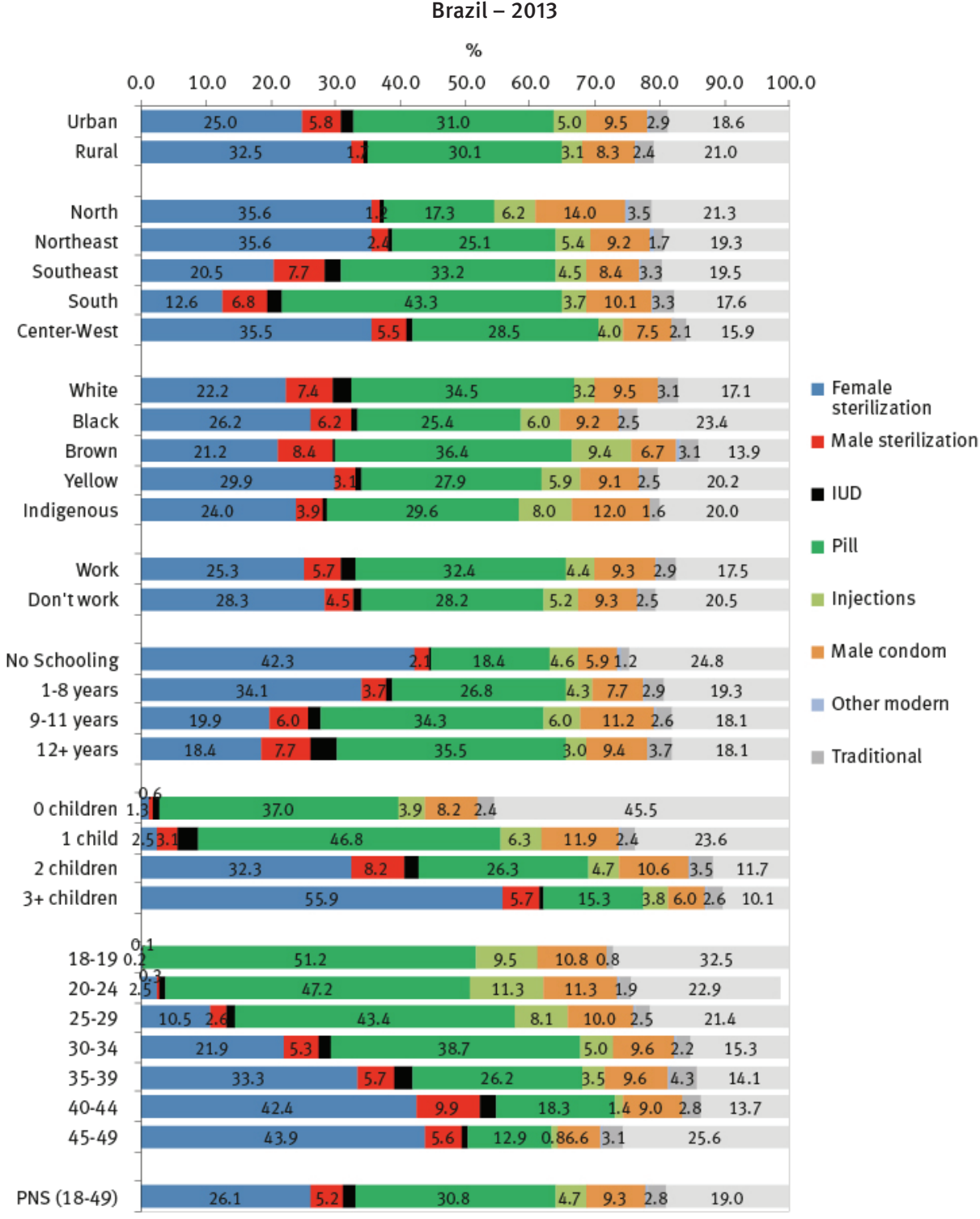

Source: IBGE, Pesquisa Nacional de Saúde, 2013.

(1) Data adjusted by contraceptive use coverage. 


\section{Some legacies of the Brazilian fertility transition}

The narrow and outmoded contraceptive method mix indicates not only that reproductive rights were denied at the beginning of fertility decline, but also penalized women's reproductive lives in many ways. Faced with inadequate access to fertility control, as can be imagined, couples, mainly women, have found some unorthodox and some very foreseeable path to achieve fertility regulation as discussed by Potter (1999), as the high unnecessary c-sections during the 1990's.

Female sterilization has been available in the public health system since 1999, and it does not need to be performed during a c-section anymore. However, the rates of birth by cesarean section are still extremely high in Brazil: $52 \%$ of all births occurred in hospitals were by cesarean sections, and most impressively, whereas $46 \%$ of all births occurred in the public sector hospital were by c-sections, in private hospitals this figure rises to $88 \%$ (BIRTH IN BRAZIL, 2012). Hence, forbidden female sterilization at birth in the law, to avoid unnecessary c-sections, did not have the expected result.

Another consequence, which unfortunately could have been minimized with adequate contraception, affects the survival of women. In the past, several women have died during their reproductive lives due to unsafe abortion, because family planning access was scarce (MARTINE, 1996). With the increase and currently very high prevalence of modern contraception, it would be expected that abortion would be kept to a minimum, but as Singh and colleagues (2018) show, that is not yet the case for Latin American countries, including Brazil.

An important aspect to take into account to understand contraceptive transition is the legislation on abortion, or even more important, the aspects related to abortion access regardless of the existing laws. In the case of Brazil, induced abortion is criminalized with prison for women and the professionals who performed the procedure, with three exceptional situations. ${ }^{6}$ However, voluntary and induced pregnancy interruption happens quite frequently (SINGH et al., 2018) to a variety of costs, from the most unsafe to the safest procedures (LE et al., 2014). Indeed, similar to what Brazilians have witnessed for a long time with female sterilization, which, although criminalized, was still widely practiced. The decision of contraceptive use, and more specifically the type of method selected, depends on the possibilities and costs (and knowledge) of a possible pregnancy interruption to prevent having an extra-child. That is, this relates to an aspect discussed by Biddlecom and Kantarova (2013), where method mix effectiveness scores must take into account the aspects related to becoming pregnant while using a method.

Trends and patterns of fertility tell another part of this history. Fertility decline in Brazil have started for some specific population segments even before the 1960's, mainly among the wealthiest and most educated. Regionally, the onset of fertility transition had

\footnotetext{
${ }^{6}$ The legislation allows for terminating pregnancy that is result of rape, if women are in life threatening condition and for anencephaly or fetus with malformation incompatible with extra-uterine life.
} 
different starting periods in the country (POTTER et al., 2010), but on national average, fertility transition started around mid-1960's, with TFR declining from 6 children per women to about 1.9 or 1.7 children in $2010^{7}$ (CAVENAGHI; ALVES, 2016; CASTANHEIRA; KOHLER, 2016, CARVALHO; GONÇALVES; SILVA, 2018). In a large and unequal country, this process of declining fertility did not occur homogeneously across space and time, as a longitudinal analysis of fertility transition at micro-region level have shown (POTTER et al., 2010). Compared to the European standards of fertility transition, overall, Brazilian transition occurred at a very fast pace, and currently the rates are in the final stage of convergence at geographical level.

The fast fertility transition, under deficient reproductive health access, has contributed to imprint specific characteristics to the current Brazilian fertility, which can be acknowledged as adverse legacies. The first legacy pointed out here is the socioeconomic differential in TFR estimates, ranging from three children to less than one child per woman in $2015,{ }^{8}$ for women according to completed years of schooling and income quintiles (Graphic A1, Appendix). ${ }^{9}$ That is, even with an average below replacement level, some population segments across the country have fertility well above reported preferences (BRASIL, 2009), which is generally associated to failure in the access or practice of contraception.

Another peculiar feature worth noting is the age specific fertility rates in the country (Graph A2, Appendix). First is the presence of high adolescent and youth fertility at very low total fertility rate. Indeed, the age schedule of fertility presents a very young pattern, indicative of fertility regulation by parity control, not by spacing along the reproductive period or by postponement of first births. The concentration of fertility at young ages is a feature that contrasts with the low total fertility rate, because, relatively to the TFR level, the country has one of the highest teenager fertility rates in the world (RODRIGUEZVIGNOLI, 2017). Second, postponement fertility appears to happen only to women with 12 or more years of schooling (completed and not completed superior education), and according to income, the two poorest quintiles still did not present any sign of current fertility postponement.

Some scholars argue that this different behavior among socioeconomic groups, mainly among adolescents, is due to higher fertility preferences among the poor segments of the population (HEILBORN, 2005; OLIVEIRA; VIEIRA, 2010), but this is not reflected in the very high rates of mistimed and unwanted pregnancies, as recorded in the PNDS 2006 (Graphs A3 and A4). These outdated results seem not to have changed much since a more recent

\footnotetext{
${ }^{7}$ This variation is due to estimates from different data sources, and none of them can be considered the most accurate, since all data and methods applied present problems. This is an unfortunate situation for the country, not only for fertility estimates, but also for all other demographic indicators, including contraceptive prevalence, as will be discussed later in this paper.

${ }^{8}$ The National Household Survey (PNAD) of 2015 was the last year a household survey collected information on fertility, since the annual PNADs were discontinued and the new continuous survey still did not collect proper information on parity and current fertility.

${ }^{9}$ It is important to note that the PNAD did not correct reported population by age, thus fertility estimates present some estimation problems. All estimates are reproduced in the Appendix to facilitate theobservation of the aspects discussed here.
} 
national survey, ${ }^{10}$ with data collected in hospitals at the post-birth situation, indicated that unintended pregnancy, including mistimed and unwanted pregnancy, is still very high, since only $44.6 \%$ of the mothers reported the birth was wanted at that time (THEME-FILHA, 2016, p. 236). The percentage of mistimed and unwanted birth varies by age and socioeconomic groups (UNFPA, 2018a), and unintended fertility is even higher for younger women.

Countries with very low fertility rates generally follow an age pattern of fertility postponement, where women prevent pregnancy early in life with long-acting, but not permanent contraceptive methods. They then learn the means and ends to an effective and not permanent method, since methods are primarily used for postponement. In Brazil, however, and several developing countries, most births occur early in life, most time before any use of contraceptive.

Not only is teenager fertility high, but also the mode of fertility is among women aged 20-24. This will put large proportions of women at young ages, younger than 30 , already reaching the desired number of children and with a long period to prevent an extra-child (control by termination and not postponement), with no previous experience and sufficient information on reliable methods. This might help explain why female sterilization still has high demand, and in several parts of the country, an unsatisfied demand.

These adverse legacies caused by inadequate access to reproductive rights are probably current causes for the perpetuation of some behaviors related to contraceptive use. However, any actions, programs or laws seeking to affect these behaviors directly, not based on each individual's intrinsic right to have appropriate information and means to voluntarily regulate fertility, will cause further unintended and adverse consequences.

\section{Final remarks}

The most recent State of the World Population (UNFPA, 2018b) addressed the topic of fertility transition, drawing attention to the power of choice in realizing fertility preferences. When contraceptive choices are in question, the practice observed everywhere makes it clear that the word "choice" should appear between quotation marks in most countries. Whose choice? Choice based on what information? Choice under what type of constraints? By looking at the past trends and the current situation of contraceptive method mix in Brazil, as discussed here, it seems that choices are very limited.

The analysis of contraceptive prevalence rates for specific methods presented here has not only confirmed that changes during these last 20 years have been slow, but also took a pathway to a still more outmoded regime, with a huge increase of the pill as most prevalent method among married and in-union women. Moreover, the prevalence of male contraception is very low and IUD and implants seem to be out of reach for most people,

\footnotetext{
10 These data are not directly comparable. The different methodology would indicate that the reported unwanted or mistimed births would be higher in the post-births situation due to less time for rationalization. However, the process around this is complex and very detailed research is needed to indicate the level of comparability among the estimates from these different surveys.
} 
whether rich or poor. Even more worrisome is that this outmoded pattern of contraceptive method mix can account for much of the high fertility at young ages, with a high mistimed fertility, and also high percentages of unwanted pregnancy, apart from the maternal mortality due to unsafe abortions not discussed here.

Hence, not only does the pattern of contraceptive method mix indicate something is wrong with the timely and appropriate access to contraception in Brazil, but it can also partially explain the negative consequences of fast fertility transition under constraints in access to contraception. First, even after reaching low fertility, way below replacement level, there are large socioeconomic differences in fertility level and schedule, indicating that women are not using the most appropriate method when starting sexual activity. Furthermore, even after using contraception, the high rates of unwanted and mistimed fertility, by socioeconomic groups and age, show high failure rates in the use of contraceptives. Therefore, although it may seem the low fertility in the country implies there is no problem in universal reproductive access, the adverse characteristics of this low fertility indicate problems for women achieving fertility preferences remain.

Regulating fertility and achieving preferences is very complex. Apart from access to the means, conception and contraception, for people to achieve fertility self-determination, they need the right information and knowledge to deal with adverse situations in life course. The most effective way to achieve knowledge and acquire the means to exercise rights in the realm of sexual and reproductive health is comprehensive and quality sex education during life course. Failure to take the current situation of sex education in Brazil seriously, and failure to provide universal access to contraception in the entire territory, in the next 20 years, method mix will be even more outdated.

Finally, regarding data production, there is an urgent need for planning. Although the country has achieved low fertility, this paper clearly shows that sexual and reproductive health is a major policy concern. In spite of that, Brazilian data producers and policymakers have not put much attention and resources in collecting adequate data to better inform policies on reproductive health. Hence, it is urgent to change this in the near future, because the laissez-faire approach, not producing timely and accurate data and not involving experts in this planning, are also outmoded practices.

\section{References}

ALVES, J. E. D. The context of family planning in Brazil. In: CAVENAGHI, S. (org.). Demographic transformations and inequalities in Latin America: historical trends and recent patterns. Rio de Janeiro: Alap, 2009. p. 297-302. (Serie Investigaciones, n. 8). Available at: 〈http://www.alapop. org/alap/Serielnvestigaciones/InvestigacionesSI1aSi9/DemogTrans formations.pdf〉.

ALVES, J. E. D.; CORRÊA, S. Demografia e ideologia: trajetos históricos e os desafios do Cairo+10. Revista Brasileira de Estudos de População, v. 20, n. 2, p. 129-156, 2003.

ALVES, J.E.D.; MARTINE, G. Population, development and environmental degradation in Brazil. In: LENA, P.; ISSBERNER, L. R. Brazil in the Anthropocene: conflicts between predatory development and environmental policies. London; New York: Routledge, 2017. 
BERQUO, E.; CAVENAGHI, S. Direitos reprodutivos de mulheres e homens face à nova legislação brasileira sobre esterilização voluntária. Cadernos de Saúde Pública, Rio de Janeiro, v. 19, supl. 2, p. S441-S453, 2003. Available at: 〈http://dx.doi.org/10.1590/S0102-311X2003000800025〉.

BERQUÓ, E.; CAVENAGHI, S. M. Increasing adolescent and youth fertility in Brazil: a new trend or a one-time event? In: ANNUAL MEETING OF THEPOPULATION ASSOCIATION OF AMERICA. Proceedings [...]. Philadelphia, PA: Population Association of America, 2005.

BERQUÓ, E.; LIMA, L. P. de. Planejamento da fecundidade: gravidezes não-desejadas - PNDS 1996 e 2006. In: BRASIL. Ministério da Saúde. Pesquisa Nacional de Demografia e Saúde da Criança e da Mulher - PNDS 2006: dimensões do processo reprodutivo e da saúde da criança. Brasília: Ministério da Saúde, Centro Brasileiro de Análise e Planejamento, 2009. p. 136-149.

BIDDLECOM, A.; KANTAROVA, V. Global trends in contraceptive method mix and implications for meeting the demand for family planning. In: IUSSP INTERNATIONAL POPULATION CONFERENCE. Proceedings [...]. Busan, Republic of Korea: IUSSP, 2013.

BRASIL. Ministério da Saúde. Pesquisa Nacional de Demografia e Saúde da Criança e da Mulher - PNDS 2006: dimensões do processo reprodutivo e da saúde da criança. Brasília: Ministério da Saúde, Centro Brasileiro de Análise e Planejamento, 2009.

BONGAARTS, J.; CLELAND, J.; TOWNSEND, J.; BERTRAND, J.; DASGUPTA, M. Family planning programs for the 21st century: rationale and design. New York: Population Council, 2012.

BONGAARTS, J.; JOHANSSON, E. Future trends in contraception in the developing world: prevalence and method mix. Studies in Family Planning, v. 33, n. 1, p. 24-36, 2002.

CAETANO, A. J.; POTTER, J. E. Sterilization for votes in the Brazilian northeast: the case of Pernambuco. Population and Development Review,v. 30, n. 1, p. 79-108, 2004.

CANESQUI, A. M. Planejamento familiar nos planos governamentais. Revista Brasileira de Estudos de População, v. 2, n. 2, p. 1-20, 1985.

CARVALHO, J. A. M. de; BRITO, F. A demografia brasileira e o declínio da fecundidade no Brasil: contribuições, equívocos e silêncios. Revista Brasileira de Estudos de População, v. 22, n. 2, p. 351-369, 2013.

CASTANHEIRA, H. C.; KOHLER, H.-P. It is lower than you think: recent total fertility rates in Brazil and possibly other Latin American countries. In: ANNUAL MEETING POPULATION ASSOCIATION OF AMERICA. Proceedings [...]. Washington, DC: Population Association of America, 2016.

CARVALHO, J. A. M; GONÇALVES, G. Aplicação da técnica P/F de Brass em um contexto de rápida queda da fecundidade adolescente. Revista Brasileira de Estudos de População, v. 35, n. 1, p. 1-26, 2018.

CAVENAGHI, S. Bases de dados para o estudo da saúde sexual e reprodutiva. In: CAVENAGHI, S. (org.). Indicadores municipais de saúde sexual e reprodutiva. Rio de Janeiro; Brasília: Abep, UNFPA, 2006. p. 77-110. Available at: 〈http://www.unfpa.org.br/Arquivos/indicadores.pdf〉.

CAVENAGHI, S. La planificación reproductiva en AméricaLatina: legislaciones y prácticas de la concepcióny contracepción. In: WONG. L. R. (org.). Avances y retrocesosen la salud sexual y reproductivaen América Latina. Rio de Janeiro: Alap, 2009. (Serie e-Investigaciones, n. 1).

CAVENAGHI, S. M.; ALVES, J. E. D. Qualidade das informações sobre fecundidade no Censo Demográfico de 2010. Revista Brasileira de Estudos de População, v. 33, n. 1, p. 189-206, 2016. Available at: 〈http://dx.doi.org/10.20947/S0102-309820160010〉.

CAVENAGHI, S. M.; ALVES, J. E. D. Fecundidade e dinâmica da população brasileira. Brasília: UNFPA, 2019. 
CELADE - Centro Latinoamericano y Caribeño de Demografía; CFSC - Centro de Estudios de la Comunidad y la Familia. Fertility and family planning in metropolitan Latin America. Chicago: University of Chicago, 1972.

CEPAL - Comisión Económica para América Latina y el Caribe. La planificación familiar en América Latina. Santiago, DDR/7, 1992.

HUMANAE VITAE. Carta encíclica de Sua Santidade o Papa Paulo VI sobre a regulação da natalidade. Roma, 25/07/1968. Available at: 〈https://w2.vatican.va/content/paul-vi/pt/ encyclicals/documents/hf_p-vi_enc_25071968_humanae-vitae.html〉.

IBGE - Instituto Brasileiro de Geografia e Estatística. Estatísticas do Século XX no Anuário Estatístico do Brasil, 1985. Rio de Janeiro, v. 46, 1985.

IBGE - Instituto Brasileiro de Geografia e Estatística. Pesquisa Nacional de Saúde - 2013. Questionário. Rio de Janeiro, s.d. Available at: 〈https://ww2.ibge.gov.br/home/estatistica/ populacao/pns/2013/default_microdados.shtm>.

IBGE - Instituto Brasileiro de Geografia e Estatística; UNFPA - Fundo de População das Nações Unidas. Projeto BRA/98/P08: Sistema Integrado de Projeções e Estimativas Populacionais e Indicadores Sociodemográficos.

HEILBORN, M. L. O ultra-som de uma "tragédia nacional". Resultado: a gravidez precoce não é o drama que se noticia. 0 Estado de S. Paulo, caderno Aliás, 20 de fevereiro de 2005.

ICF. The DHS Program STATcompiler. Funded by USAID, 2012. Available at: 〈http://www. statcompiler.com>. Access in: Mar., 15, 2019.

LAGO, T. D. G. do. Nascimentos não planejados no Brasil eram 46\% em 2006. Diminuíram? Revista Brasileira de Estudos de População, v. 32, n. 2, p. 387-394, 2015.

LE, H. H. et al. The burden of unintended pregnancies in Brazil: a social and public health system cost analysis. International Journal Women's Health, v. 6, p. 663-670, 2014.

MARTINE, G. Formación de la familia y marginalidad urbana en Río de Janeiro. Santiago de Chile: Celade, 1975.

MARTINE, G. Brazil's fertility decline, 1965-95: a fresh look at key factors. Population and Development Review, v. 22, n. 1, p. 47-75, 1996.

MARTINE, G.; FARIA, V. Contexto social da política e da pesquisa em população no Brasil. Revista Brasileira de Estudos de População, v. 3, n. 1, p. 1-23, jan./jun. 1986.

OLIVEIRA, M. C.; VIEIRA, J. M. Gravidez na adolescência e bem-estar infantil: evidências para o Brasil em 2006. Revista Latinoamaericana de Población, v. 3, n. 6, p. 12-39, 2010.

OLSEN, J. M. et al. Práticas contraceptivas de mulheres jovens: inquérito domiciliar no Município de São Paulo, Brasil. Cadernos de Saúde Pública, v. 34, n. 2, 2018. Available at: 〈http://dx.doi. org/10.1590/0102-311x00019617>.

PAIVA, P. de T. A. O processo de proletarização e a transição da fecundidade no Brasil. Revista Brasileira de Economia, v. 41, n. 4, p. 383-414, out. 1987.

PATARRA, N. L.; OLIVEIRA, M. C. F. A. Transição, transições. In: ENCONTRO NACIONAL DE ESTUDOS POPULACIONAIS, 6. Anais [...]. Olinda, PE: Abep, 1988. v. 1, p. 17-36.

PEIPERT, J. F. et al. Continuation and satisfaction of reversible contraception. Obstetrics and Gynecology, v. 117, n. 5, p. 1105-1113, 2011. 
PERPÉTUO, I. H. O.; RODRIGUEZ WONG, L. L. Desigualdade socioeconômica na utilização de métodos anticoncepcionais no Brasil: uma análise comparativa com base nas PNDS 1996 e 2006. In: BRASIL. Ministério da Saúde. Pesquisa Nacional de Demografia e Saúde da Criança e da Mulher - PNDS 2006: dimensões do processo reprodutivo e da saúde da criança, Brasília: Ministério da Saúde, Centro Brasileiro de Análise e Planejamento, 2009. p. 87-104.

POTTER, J. E. The persistence of outmoded contraceptive regimes: the cases of Mexico and Brazil. Population and Development Review, v. 25, n. 4, p. 703-739, 1999.

ROSS, J.; KEESBURY, J.; HARDEE, K. Trends in the contraceptive method mix in low- and middle income countries: analysis using a new "Average Deviation” measure. Global Health: Science and Practice, v. 3, n. 1, p. 34-55, 2015.

SINGH, S. et al. Abortion worldwide 2017: uneven progress and unequal access. New York: Guttmacher Institute, 2018.

RODRÍGUEZ-VIGNOLI, J. Fecundidad no deseada entre las adolescentes latinoamericanas: un aumento que desafía la salud sexual y reproductiva y el ejercicio de derechos. Santiago de Chile: Cepal, 2017. (Serie Población y Desarrollo, n. 119).

SIMMONS, A. E.; CONNING, A.; VILLA, M. (ed.). El contexto social de cambio de la fecundidad en América Latina rural. Aspectos metodológicos y resultados empíricos, volúmenes I-III. Santiago de Chile: Cepal, 1979.

TAUCHER, E. Efectos demográficos y socio-económicos de los programas de planificación familiar en la América Latina. In: URQUIDI, V.; MORELOS, J. B. (org.). Población y desarrollo en América Latina. México D.F.: Centro Latinoamericano de Demografía (Celade), Comisión Económica para América Latina y el Caribe (Cepal), Colegio de México, 1979.

THEME-FILHA, M. et al. Factors associated with unintended pregnancy in Brazil: cross-sectional results from the birth in Brazil National Survey, 2011/2012. Reproductive Health, v. 13, p. 235265, 2016.

TRUSSELL, J. Contraceptive failure in the United States. Contraception, v. 83, n. 5, p. 397-404, 2011.

UNITED NATIONS. Department of Economic and Social Affairs. Population Division. World contraceptive use 2015 (POP/DB/CP/Rev2015), 2015.

UNITED NATIONS. Department of Economic and Social Affairs. Population Division. World contraceptive use 2017. New York: United Nations, 2017. Available at: 〈http://www.un.org/en/ development/desa/population/publications/dataset/contraception/wcu2017.shtml>.

UNITED NATIONS. Department of Economic and Social Affairs. Population Division. World contraceptive use 2018 (POP/DB/CP/Rev2018), 2018.

UNFPA - Fundo de População das Nações Unidas. Universal access to reproductive health: progress and challenges. New York: UN, jan. 2016. Available at: 〈https://www.unfpa.org/ publications/universal-access-reproductive-health-progress-and-challenges〉.

UNFPA - Fundo de População das Nações Unidas. Fecundidade e dinâmica da população brasileira. Brasília, 2018a. Available at: 〈https://brazil.unfpa.org/sites/default/files/pub-pdf/ swop_brasil_web.pdf〉.

UNFPA - Fundo de População das Nações Unidas. State of world population 2018: the power of choice -reproductive rights and the demographic transition. New York: UN, 2018b. Available at: 〈https://doi.org/10.18356/ff31c49d-en〉. 


\title{
About the authors
}

Suzana Cavenaghi is independent researcher with $\mathrm{PhD}$ in Demography/Sociology from the University of Texas at Austin.

José Eustáquio Diniz Alves is independent researcher with $\mathrm{PhD}$ in Demography from the Centro de Desenvolvimento e Planejamento Regional (Cedeplar) at the Universidade Federal de Minas Gerais (UFMG), and post-doc from Núcleo de Estudos de População (Nepo) at the Universidade Estadual de Campinas (Unicamp).

\section{Contact address}

\author{
Suzana Cavenaghi \\ Praia do Flamengo, 98 apto. 209, Flamengo \\ 22210-030 - Rio de Janeiro-RJ, Brazil \\ José Eustáquio Diniz Alves \\ Praia do Flamengo, 98 apto. 209, Flamengo \\ 22210-030 - Rio de Janeiro-RJ, Brazil
}

\section{Resumo}

\section{O mix contraceptivo eternamente obsoleto no Brasil e seu legado}

A transição da fecundidade ocorreu de maneira rápida no Brasil na ausência de programas de planejamento familiar e, mais impressionante, em um contexto de ilegalidade na provisão dos meios para a autorregulação da fecundidade. Esses eventos não ocorreram sem consequências. Com base na literatura e nos fatos registrados durante esse período, o artigo discute, primeiro, como a resistência à implementação de programas de planejamento familiar nas décadas de 1960 a 1980 contribuiu para o mix contraceptivo obsoleto, já nos anos 1990. Em segundo lugar, abordando os problemas em torno da coleta de dados de contracepção na Pesquisa Nacional de Saúde e fazendo um ajuste nos dados, são analisadas as tendências na prevalência contraceptiva de 1986 a 2013, mostrando que o mix de métodos continua muito concentrado nos mesmos dois métodos, um regime ainda mais obsoleto, com a pílula diária trocando de lugar com a esterilização feminina. Por fim, são discutidas algumas características da fecundidade associadas ao mix contraceptivo obsoleto, que ainda prevalece no final da transição da fecundidade. Argumenta-se que isso poderia ser evitado ou minimizado se políticas e leis fossem baseadas apenas nos direitos reprodutivos de todas as pessoas.

Palavras-chave: Anticoncepção. Planejamento familiar. Brasil. Comportamento reprodutivo.

\section{Resumen}

El mix anticonceptivo eternamente obsoleto en Brasil y su legado

La transición de la fecundidad se dio rápidamente en Brasil en ausencia de programas de planificación familiary, más sorprendentemente, en un contexto de ilegalidad en la provisión de los medios para la autorregulación de la fecundidad. Esos eventos no ocurrieron sin consecuencias. Con base en la literatura y los hechos registrados durante ese período, el artículo 
analiza primero cómo la resistencia a la implementación de programas de planificación familiar en los años sesenta a ochenta resultó en el mix de contraceptivos obsoleto de los noventa. En segundo lugar, analizando los problemas relacionados con la recopilación de datos de la Encuesta Nacional de Salud, y ajustándolos, se analizan las tendencias en la prevalencia de los anticonceptivos de 1986 a 2013, lo que demuestra que el mix de métodos sigue estando muy centrado en los mismos dos métodos, un régimen aún más obsoleto, con la píldora diaria intercambiando el primer lugar con la esterilización femenina. Finalmente, se discuten algunas características de fecundidad asociadas con el mix anticonceptivo obsoleto, que aún prevalecen al final de la transición de fecundidad. Se argumenta que esto podría evitarse o minimizarse si las políticas y leyes se basaran en los derechos reproductivos de todas las personas.

Palabras clave: Anticoncepción. Planificación familiar. Brasil. Comportamiento reproductivo.

Received for publication in 04/10/2019 Approved for publication in 04/11/2019 


\section{APPENDIX}

GRAPH A1

Total fertility rates by completed years of education and per capita household income quintiles Brazil - 2015

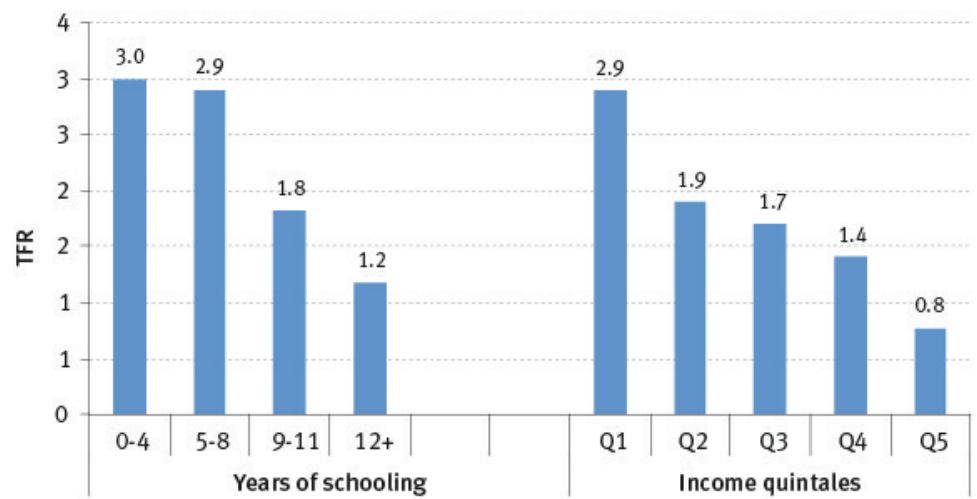

Source: IBGE. Pesquisa Nacional por Amostra de Domicílios, 2015 microdata.Corrected estimates due to age undercount.

GRAPH A2

Age specific fertility rates and total fertility rates (1) by completed years of education and per capita household quintiles

Brazil - 2015
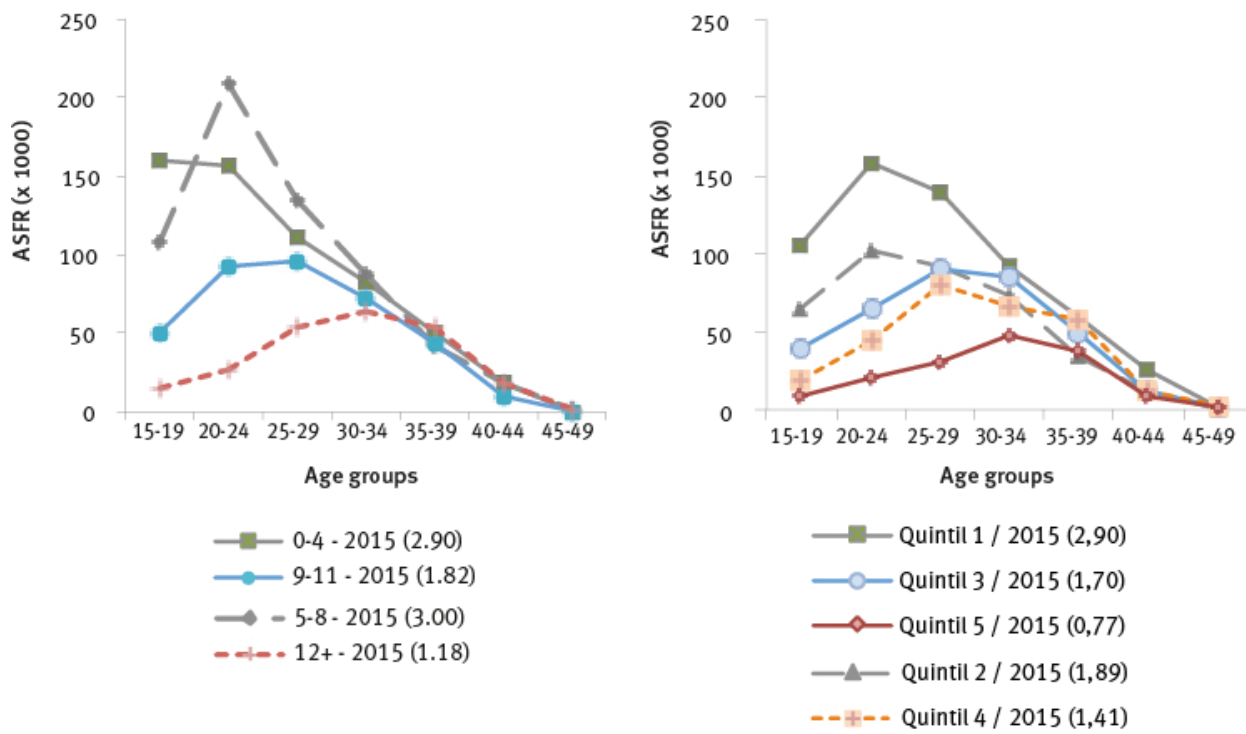

Source: IBGE. Pesquisa Nacional por Amostra de Domicílios, 2015 microdata.Corrected estimates due to age undercount (1) TFR in parenthesis in the legend. 
GRAPH A3

Distribution of wanted, mistimed and unwanted births occurred in the 5 -years prior to the interview, by mother's age

Brazil - 2006

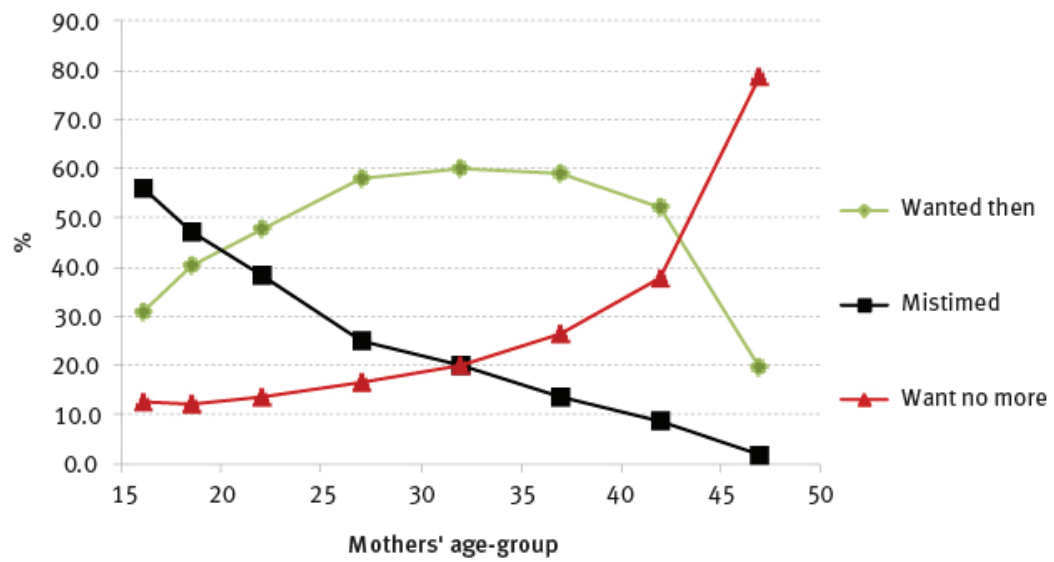

Source: Pesquisa Nacional de Demografia e Saúde, PNDS, 2006.

GRAPH A4

Distribution of wanted, mistimed and unwanted births occurred in the 5 -years prior to the interview, by mother's age and completed years of schooling

Brazil - 2006

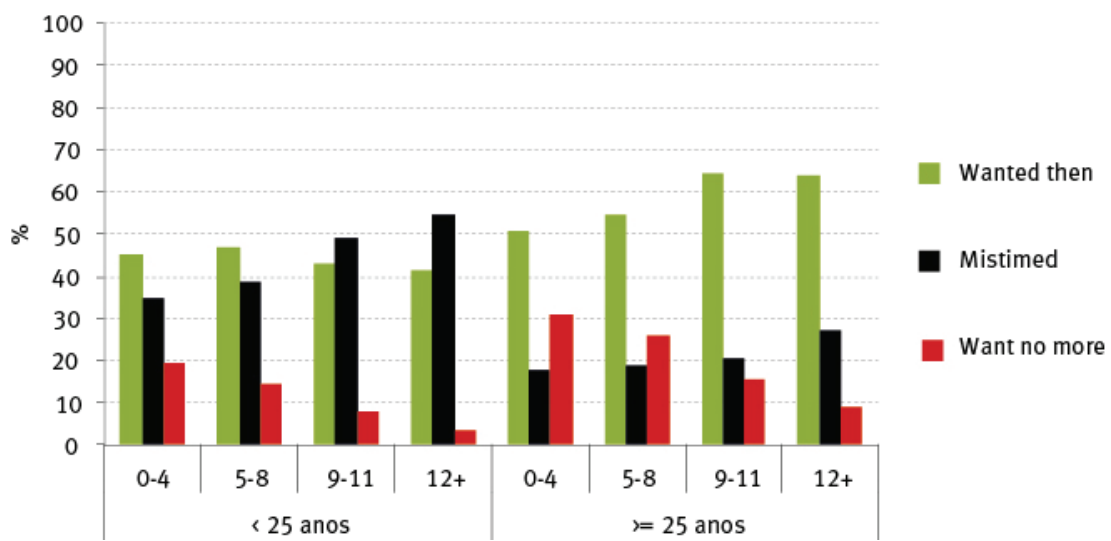

Source: Pesquisa Nacional de Demografia e Saúde, PNDS, 2006. 